\title{
ETHNOBOTANICAL STUDIES ON FLORAS USED FOR STORAGE IN BAYELSA STATE, NIGERIA
}

\author{
Ihinmikaiye, Samuel Olatokunbo, \\ ${ }^{1}$ Department of Plant Science and Biotechnology, Federal University Otuoke, Nigeria \\ Ihinmikaiye.samuel@yahoo.com \\ Ochekwu, Edache Bernard, \\ ${ }^{2}$ Department of Plant Science and Biotechnology, University of Port Harcourt,Nigeria \\ edacheb@gmail.com \\ Ikuli, Josiah Muonam \\ ${ }^{3}$ Department of Crop and Soil Science, Niger Delta University Bayelsa State, Nigeria \\ ikulijosiah@yahoo.com \\ DOI: $10.31364 /$ SCIRJ/v8.i12.2020.P1220826 \\ http://dx.doi.org/10.31364/SCIRJ/v8.i12.2020.P1220826
}

\begin{abstract}
Ethnobotanical study on the plant species used for storage was carried out within forty communities in Bayelsa State. Eight plant species belonged to six different families were identified as botanicals valued for storage and preservative purposes, most of which are herbs. The result revealed that the plant species identified were alleged to be safe, available and exhibit different growth habits. However, two of the species (Braschystegia nigerica and Xylopia aethiopica) are trees, and are rare as they served other primary uses. Different sections of the plant species were extracted for storage purposes, and members of Marantaceae were the most exploited for storage. As the pattern of plants use among locals becomes ecologically unsustainable, there is a need to document the floras use for storage purposes and determine their abundant status in the State.
\end{abstract}

Keywords: storage, preservation, plant materials, postharvest, Bayelsa State

\section{Introduction}

Ethnobotany, the study of the relationship between man and his ambient vegetation (Schultes, 1941) is an important aspect of plant conservation; particularly the preservation of undocumented indigenous knowledge of plant used by tribal communities (EDB, 2015), for various purposes such as oral care, shelter, storage, medicine and craft (Obute and Ekiye, 2008; Ihinmikaiye and Tanee, 2014; Sejabaledi, 2016). Plants are essentially useful to tribal people. The knowledge of plant used for storage is a strategy that can be linked to the conservation of biodiversity and the preservation of postharvest food stuff. It has been reported that regions rich in biological diversity are usually inhibited by cultural group who have manage to hold traditional ecological knowledge of their bioregions (Turner et al., 2002; Serge, 2003). Such is the case in Bayelsa, a State rich in cultural diversity, whose indigenes depends

\section{www.scirj.org}

(C) 2020, Scientific Research Journal

http://dx.doi.org/10.31364/SCIRJ/v8.i12.2020.P1220826

This publication is licensed under Creative Commons Attribution CC BY. 
mostly on subsistence harvests of non-timber forest products (NTFPs) and fishery for their livelihood, they rely on oral knowledge gained by generations of interaction with nature and vegetation, for the preservation and storages of postharvest products. Storage of harvested produce of any kind is important for food conservation and management (Yallappa et al., 2011). It has been recognized that plant species play an important role in the preservation of harvested produce by exerting pesticidal properties and or biological activity against a wide range of pests (Khatun, 2011; Ogbaji and Osuman (2011). Neem (Azadirachta indica) materials among others have been well reported by many researchers as grain protectants against grain storage insects (Jilani and Su, 1983; Yadar, et al., 2007; Khatun et al., 2011). A number of plant species has been used as important tools for storage and wrapping of food among the indigenous people Bayelsa State. This study evaluates the botanicals used for storage and preservation of food in the Bayelsa State, it also seeks to know their abundant status, and the acceptability level among the indigenous people.

\section{Materials and Methods}

Ihinmikaiye et al. (2016) had provided the detailed description of the study area, and the delineation of the State into three districts (on the basis of the existing senatorial coordination of Nigeria) was maintained in the study. Social survey and direct field observation was used in the study (after kayode, 2005). The districts are Bayelsa East (BE), Bayelsa West (BW) and Bayelsa Central (BC). In each district, five villages each relatively free from urban influence were randomly selected from each local government area (LGA) that makes up the senatorial districts in the State. In all forty villages were selected from the State for the study, and five indigenous people that have maintain continuous domicile in the villages for a period not less than ten years were selected and interviewed with the aid of semi-structured question matrix. Group consensus on the floras use for storage was determined in each of the community by way of coordinated group interviews. The voucher specimens of the floras were collected, identified and relevant information gathered on them was documented. Subsequently, the abundant of the plant species was determined within a kilometer range from the center of each village sampled, by using the time taken to physically encounter the plant species. Species encountered in $<1$ hour were considered as abundant, those encountered between 1- 23 hours; between 24 hours - 3 days and between 4 days - 1 weeks were considered as frequent, occasional and rare respectively.

\section{Results and Discussion}

Interview conducted with the respondents showed that they were all aware of one form of botanical or another used for storage purposes irrespective of their sex, age, occupation, economic status and religion affiliate (Table 1).

WWW.scirj.org

(C) 2020, Scientific Research Journal

http://dx.doi.org/10.31364/SCIRJ/v8.i12.2020.P1220826

This publication is licensed under Creative Commons Attribution CC BY. 
Table1: Socio-economic Factures of Respondents in the Study Area

\begin{tabular}{lllll}
\hline Feature & & Bayelsa West & Bayelsa Central & Bayelsa East \\
\hline Sex & Male & 15 & 28 & 39 \\
& Female & 35 & 47 & 36 \\
Age & & & 10 & 9 \\
& $<20$ & 22 & 52 & 43 \\
& $20-65$ & 15 & & 22 \\
Occupation & $>60$ & & 67 & 61 \\
& & 39 & 8 & 14 \\
Economic Status & Agriculture & & & 28 \\
& Non-Agriculture & 11 & 31 & 38 \\
& & & 29 & 9 \\
Religion & Small & 29 & 15 & 71 \\
& Medium & 5 & 68 & - \\
& Large & & 1 & 4 \\
\hline
\end{tabular}

However, they are unwary of the ecological implications of unsustainable use of the plant species. Eight (8) plant species belonged to six (6) different families were used for storage purpose in the study area. Two of the plant species accessed for storage are trees, and were rare. The species exhibited different growth habits and the perceptions of the respondents with respect to the species' abundant status are presented in the Table 2.

Table 2: Name and Status of Plants Used for Storage Among Indigenous People of the Study Area

\begin{tabular}{|c|c|c|c|c|c|}
\hline Botanical name & Voucher number & Ijaw name & Family & $\begin{array}{l}\text { Abundant } \\
\text { Status }\end{array}$ & Habit \\
\hline $\begin{array}{l}\text { Braschystegia nigerica (Hoyle } \\
\text { \& J.) }\end{array}$ & UHAE2019-628 & okolodo & Fabaceaea & rare & tree \\
\hline $\begin{array}{l}\text { Calamus deerratus (G. Mann. } \\
\& \text { H. W.) }\end{array}$ & UHAE2019-633 & apie & Arecaceae & frequent & liana \\
\hline $\begin{array}{l}\text { Marantochloa leucantha } \\
\text { K.Schum }\end{array}$ & UHAE2019-718 & abelebei & Marantaceae & " & herb \\
\hline $\begin{array}{l}\text { Marantochloa purpurea (Ridl.) } \\
\text { Milne-R. }\end{array}$ & UHAE2019-719 & $"$ & $"$ & $"$ & herb \\
\hline $\begin{array}{l}\text { Musa sapientum var. } \\
\text { paradisiaca (L.) }\end{array}$ & UHAE2019-728 & beriba & Musaceae & abundant & herb \\
\hline Occimum gratissimum (L.) & UHAE2019-733 & furukana & Lamiaceae & " & shrub \\
\hline $\begin{array}{l}\text { Thaumatococcus danielii } \\
\text { (Benn.) }\end{array}$ & UHAE2019-784 & bibi belemo & Marantacea & occasional & herb \\
\hline $\begin{array}{l}\text { Xylopia aethiopica (Dunal) A. } \\
\text { Rich. }\end{array}$ & UHAE2019-795 & enge & Annonaceae & rare & tree \\
\hline
\end{tabular}

WWW.scirj.org

(C) 2020, Scientific Research Journal

http://dx.doi.org/10.31364/SCIRJ/v8.i12.2020.P1220826

This publication is licensed under Creative Commons Attribution CC BY. 
Species that were relatively abundant were mostly cultivated and their uses as medium of storage were secondary: this validates the previous claims of Azige (2015) who reported that plants are cultivated primarily for their economic values. The abundant scale suggested that $B$. nigerica (used for preserving palm vine) was rare. The tree was a highly valued timber species and it is one of the species sorted by lumberjack. Similarly, X. aethiopica which doubled as spice and medicinal plant is fast becoming rare. Its primary uses were largely unsustainable for ecological stability. Ihinmikaiye et al. (2018) affirmed that most of the methods employed in harvesting the species in the study area were inhibitory and annihilative. Members of Marantaceae were the most utilized for storage purposes in the area, perhaps a result of their leaves size and phytochemicals (Ukwubile et al., 2017).

Different sections of the plants were used for storage and preservation purposes, and the methods of their applications vary significantly. These methods ranges from steeping to wrapping, and from dispersing to synergistic blend with undisclosed local ingredients (Table 3): all these methods gear toward enhancing preservation, and discouragement of pests from harvested produce.

\begin{tabular}{|c|c|c|c|c|}
\hline Botanical name & Part used & Method of Application & produce stored & Reasons for choice \\
\hline B. nigerica & bark & steeping & palm wine & $\begin{array}{l}\text { prevents } \\
\text { fermentation }\end{array}$ \\
\hline C. deerratus & fibre & stocking & fish/crayfish & $\begin{array}{l}\text { enhances } \\
\text { preservation }\end{array}$ \\
\hline M. leucantha & leaf & wrapping & food items & $"$ \\
\hline M. purpurea & $"$ & " & " & $"$ \\
\hline M. sapientum var. & " & " & " & " \\
\hline O. gratissimum & $"$ & $\begin{array}{l}\text { combined with other } \\
\text { undisclosed ingredients }\end{array}$ & fish & $"$ \\
\hline T. danielii & $"$ & wrapping & food items & $"$ \\
\hline X. aethiopica & fruit & squashed \& spreading & grains & discourages pests \\
\hline
\end{tabular}

Most of the plants literally used for discouraging pests have repulsive smell due to the phytochemicals and essential oils embedded (MacMillian, 1984). These phytochemicals from evolutionary view are used to warn-off predators, and the plants materials provide preservative option for the indigenous people, being relatively non harmful to health and less detrimental to the environment (Mollah et al., 2017; Karunataran and Arulnandhy, 2018). Thus these botanicals could proffer solution for the problem of storage and preservation of food stuff locally or on a large scale. Yet it important that available information on the plants, especially the rare species are documented as this could ensure their conservation.

\section{Conclusion}

This study has revealed the plant species employed for farm produce conservation and also suggest that conservation of farm produce among the indigenous people is a long standing course that relied on harnessing botanicals in the natural habitat. Although most of WwW.scirj.org 
these plants serves other purposes considered as primary use, it is therefore important to enlighten the local people on the need to ensure conservation activities in the wild, and in the extraction process so as to forestall the peril of species diversity loss.

\section{Acknowledgement}

The authors are grateful to the indigenes of the communities for their hospitality and kind responses to our inquires.

\section{References}

Agize, M. (2015). Ethnobotany of Spice and Condiment Plants and the Associated Indigenous Knowledge on Management, Utilization and Conservation of them in and around Home Gardenin Loma and Gena Bosa Districts (Weredas) of Dawuro Zone, Southern Ethiopia.

Ethnobotanical Database of Bangladesh (EDB). Access from, http://www.ethnobotanybd.com/in dex.php?action=Ethnobotany

Ihimikaiye, S.O. and Tanee, F.B.G. (2014). Impacts of the Interaction of Two Automobile Workshop Wastes on the Growth Performance and Chlorophyll contents of Vigna unguiculata (L.) and Sphenostylis stenocarpa (Harm). IOSRJ 8(11): 124-137.

Ihinmikaiye, S. O.; S. Arowosegbe, J. Kayode and Oyedeji A. A. (2018). Ethnobotanical survey of plant species utilised as spices among the indigenous people of Bayelsa State, Nigeria. Brazilian Journal of Biological Sciences, v. 5, No. 10, (pp. 461-469).

Ihinmikaiye, S. O., Sunday, A., Joshua, K., and Oyedeji, A. A. (2018). Ethnobotanical survey of plant species utilised as spices among the indigenous people of Bayelsa State, Nigeria Brazilian Journal of Biological Sciences, 2018, v. 5, No. 10, p. 461469.

Jilani and SU. 1983 Effects of dried neem leaves of with grains repel the insect pests at different stages and adult life table parameter of rice moth. Journal of Economic. pp 56-60.

Kayode, J. (2005) Ethnobotanical survey and conservation of medicinal compositae species in Benin.

Karunakaran, S. and Arulnandhy, V. (2018). Insecticidal activity of selected botanicals on Maize weevil, Sitophilus zeamais (L.), in stored maize grains. DOI: http://doi.org/10.4038/agrieast.v12i1.46.

Khatun, A., Kabir, G., Bhuiyan, M. A. H. and Khanam, D. (2011). Effect of Preserved Seeds Using Different Botanicals in Seed Quality of Lentil. Bangladesh J. Agril. Res. 36(3): 381-387.

WWW.scirj.org (C) 2020, Scientific Research Journal http://dx.doi.org/10.31364/SCIRJ/v8.i12.2020.P1220826

This publication is licensed under Creative Commons Attribution CC BY. 
MacMillian, H. F. (1984). A Handbook for tropical planting and gardening. London: MacMillan Scientific Publ.

Mollah, M. A.H., Khatun,R., Hawlader, A.J., Ali. M. R., Ahmed, S., Mahmud, M. S., and Hasan, M.A. (2017). Economic Impacts of Using Botanicals Against Rice Weevils Infestation During Storage. Agricultural and Biological Sciences Journal Vol. 3, No. 3, pp. 12-27.

Obute G. C. and Ekiye, E. (2008). Ethnobotanical Applications of some Floral Species in Bayelsa State, Nigeria. Ethnobotanical Leaflets 12: 713-18.

Ogbaji, M. and Osuman, D. (2011). Insecticidal actions of some botanicals on storage bruchid, Callosobruchus maculatus (F.) of stored cowpea (Vigna unguiculataL. walp.). Agro-Science Journal of Tropical Agriculture, Food, Environment and Extension. Vol. 10 (2): 29 - 34.

Schultes, R. E. (1941). La ethnobotanica: Su acane y sus objectos. Caldasis 3:7-12.

Sejabalezdi, A. R. (2016). Sustainable use and management of indigenous plant resources: A case of Mantheding community in Limpopo province, SA. Sustainability 8, 211; doi:10.3390/su8030221

Serge, L. (2003). Common property and traditional Ecological Knowledge: Biodiversity conservation in the Sierria Tarahumara, Mexico. A thesis submitted to the Faculty of graduate studies University of Manitoba Winnipeg, Canada.

Turner, N. J. Boelscher, I. M., and Ignace, R. (2000). Traditional ecological knowledge and wisdom of Aboriginal peoples in British Columbia. Ecological Applications 10 (5): 1257-1287.

Ukwubile, C. A.; Oise, I. E.; Nyiayem , J.T., (2017). Preliminary phytochemical screening and antibacterial of Thaumactococcus daniellii Benn.) benth. Marantaceae leaf extract J. Bacteriol Mycol.4 (2) : 53 - 5. Doi:10.15406/jbmoa.2017.04.00086

Yadav, U.S., Prasad, S. S., Ram, M. and Neeraj, K. (2007). Effect of certain grain protectant oils on growth and development of angoumois grain moth, Sitotrogacerealella Olivier. Research on Crops.; 8(2): 442-445.

Yallappa, R., Nandagopal, B., and Thimmappa, S., (2012). Botanicals as Grain Protectants. Hindawi Publishing Corporation, Psyche. Vol. 2012: pp. 13. doi:10.1155/2012/646740.

WwW.scirj.org (C) 2020, Scientific Research Journal http://dx.doi.org/10.31364/SCIRJ/v8.i12.2020.P1220826 